\title{
Greasing the wheels of legal aid in criminal proceedings in Ghana: An evaluation of the legal and regulatory framework
}

\author{
Isidore Kwadwo Tufuor* \\ Barrister and Solicitor of the Supreme Court of Ghana; Lecturer, Faculty of \\ Law, Ghana Institute of Management and Public Administration (GIMPA), \\ Accra, Ghana \\ https://orcid.org/0000-0002-6191-811X
}

\section{Summary}

The provision of legal aid to deserving indigent accused persons in criminal proceedings in Ghana is fraught with numerous operational challenges. Despite the country's ratification of key international legal instruments on legal aid, its strategies for incorporating the letter and spirit of the right to legal aid in its Constitution and enabling legislations have been problematic. Furthermore, several regulatory drawbacks affect the implementation of the public legal aid schemes, especially in criminal proceedings. Consequently, a large number of accused persons, ignorant of the intricacies of the criminal adjudicatory system which is adversarial in nature, are forced despairingly to defend themselves in person at their peril. This article argues that revamping legal aid and guaranteeing its sustainability in criminal proceedings can be achieved only through a review of the normative structure of the right to legal aid and its implementation framework under the public legal aid schemes. The article concludes that the legal and regulatory frameworks governing the operations of legal aid exhibit serious shortcomings that whittle down the country's limited efforts at enforcing its international obligation to provide state-funded counsel to deserving indigent accused persons. The article adds to the general discourse on the promotion of legal aid in criminal proceedings in Ghana, where the extant scholarship primarily focuses on inadequate funding as the cause of an inefficient system.

\footnotetext{
* BA (Ghana) LLB (Ghana) DSEF (Senegal) LLM (Fordham USA) LLD(Fort Hare);
} itufuor@gimpa.edu.gh 
Key words: legal aid; indigency; accused persons; criminal proceedings; self-representation

\section{Introduction}

Representing oneself in criminal proceedings in Ghana is not always a voluntary choice or a wishful exercise of the right to selfrepresentation. ${ }^{1}$ Many accused persons ${ }^{2}$ habitually are compelled desperately to represent themselves because they are too poor to afford the undeniably high cost of legal services. ${ }^{3}$ The introduction of legal aid as a universal human rights norm plays a critical a role in guaranteeing access to free legal representation for financiallydeprived persons involved in criminal proceedings. It is in this sense that the right to legal aid earns its attributes as an 'essential element of a fair, humane and efficient criminal justice system that is based on the rule of law', 4 and also as a 'foundation for the enjoyment of other rights including the right to a fair trial'. ${ }^{5}$ Consequently, denying indigent persons access to legal aid not only violates their right to a fair trial but also constitutes an indictment of the criminal justice system of any country.

The criminal justice system of Ghana has institutionalised certain schemes of legal aid for financially-deprived accused persons in compliance with its obligations under international human rights law. ${ }^{6}$ Despite this effort, the question of accessibility to free legal services by deserving indigent accused persons nonetheless remains a matter of concern as the phenomenon of self-representation continues unabated in criminal proceedings which are of an adversarial nature. ${ }^{7}$

1 Ghanaian Constitution, art 19(2)(f), granting accused persons the right to represent themselves in criminal proceedings.

2 Where the context demands, reference to 'accused person' includes 'suspect of crime' involved in pre-trial criminal proceedings.

3 See Ghana Bar Association Scale of fees (2015). Initial consultation fees range from between $\mathrm{GH} \not 1000$ for lawyers of ten or more years' practice, to $\mathrm{GH} ₫ 500$ for lawyers with under five years of practice. For an extended initial consultation, hourly rates may range between $\mathrm{GH} \notin 1000$ and 2000 for lawyers of ten or more years' practice, and between $\mathrm{GH} ₫ 300$ and 1000 for lawyers with under five years of practice. Brief fees for bail applications in criminal trials in the High Court and circuit courts vary between $\mathrm{GH} \nsubseteq 2500$ and $\mathrm{GH} \nsubseteq 15000 ; \mathrm{GH} \nsubseteq 15000$ to $\mathrm{GH} \nsubseteq 30000$ for misdemeanour trials; $\mathrm{GH} ₫ 30000$ to $\mathrm{GH} ₫ 60000$ for felony trials; and $\mathrm{GH} ₫ 20000$ to $\mathrm{GH} ₫ 150000$ for trials on indictment. Criminal watching briefs range between $\mathrm{GH} ₫ 10000$ and $\mathrm{GH} ₫ 30000$. The prevailing exchange is approximately 1 US dollar to 5,52 Cedis.

4 United Nations Principles and guidelines on access to legal aid in criminal justice systems UN/RES/67/187 (2012) para A (1) (Annex).

5 As above.

6 See eg Latham \& Watkins 'Pro bono practices and opportunities in Ghana' (2015) The Pro Bono Institute Latham and Watkins LLP 228.

7 MK Amidu 'Right to state-appointed counsel in criminal justice administration under the Constitution' (1992) Review of Ghana Law 159. This is generally the case in most countries as they lack the necessary resources and capacity to provide 
This article particularly examines the legal and regulatory framework of legal aid delivery in criminal proceedings in Ghana. It is submitted that the ratification procedure of the right to legal aid and the regulatory framework for its implementation are beset with various legal and operational challenges affecting the efficiency and accessibility of legal aid in criminal proceedings. After this introduction, the background to legal aid in Ghana is provided through an analysis of the right to legal aid in international human rights law, the Ghanaian Constitution and the enabling statutes that set up the public legal aid schemes. This analysis is followed by an examination of the institutional framework and implementing strategies of the public legal aid schemes and a discussion of the legal complexities and operational challenges that arise. Thereafter, some workable strategies to secure the benefit of the right to legal aid to deserving indigent accused persons are explored.

\section{A universal right to legal aid in criminal proceedings}

Exercising the right to legal representation for accused persons in an adversarial criminal trial is the most immediate means by which the imbalance of trial skills and competencies between a legally-trained prosecutor and an accused is mitigated. ${ }^{8}$ However, this assumption becomes meaningless when accessibility to legal assistance is curtailed by a lack of financial means. In that case, reliance on legal aid becomes the only viable mechanism for realising the benefits of the right to legal assistance in cases of indigency.

In effect, a basic concept undergirding the operation of criminal law in modern domestic jurisdictions is that access to justice in criminal proceedings 'depends on the enforcement of the rights to due process, to a fair trial, and to legal representation'. 9 Particularly in Ghana, the values of the constitutional guarantees of legal representation for all persons involved in criminal proceedings, 10 whether suspected of having committed a crime or charged with an offence, lie in certain social realities, in that a large section of the population has very little or no knowledge of the law and its workings both in theory and in practice. These incidents therefore require the helping hand of counsel to navigate the procedural and evidentiary

legal aid for all indigent accused persons. See, eg, UN (n 4) para $A(5)$. The adversarial system pitches the parties in a legal contest where the judge is neutral and relatively passive. See Sasu v Amuah-Sekyi [1987-1988] 1 GLR 294296.

8 P Roberts \& A Zuckerman Criminal evidence (2010) 62. This observation is particularly applicable to the adversarial system.

9 Conference on Legal Aid in Criminal Justice Lilongwe Declaration on Accessing Legal Aid in the Criminal Justice System in Africa (2004) Preamble.

10 Arts $14(2) \& 19(2)(f)$ of the Ghana Constitution guarantee the right to counsel in pre-trial proceedings and during trial respectively. 
labyrinths that govern proceedings in the classical adversarial regime of criminal adjudication in Ghana. ${ }^{11}$ This observation aligns with the popular theory that even intelligent and educated lay persons cannot understand the skills of the practice of the law. ${ }^{12}$

Thus, as has been rightly posited, a trial conducted without defence counsel for the accused, in the absence of a valid waiver of legal representation, is of itself unfair. ${ }^{13}$ The trial is even more unfair in cases where the accused is deprived of legal representation simply because of poverty. ${ }^{14}$ Consequently, an assumption in the scheme of enforcement of criminal procedural rights is that where the legal system affords a theoretical right to legal assistance the state is enjoined to provide accused persons with the means to its realisation. ${ }^{15}$ In that regard, international law enjoins member states of the United Nations (UN) to provide free legal aid to individuals that lack the financial wherewithal to meet the cost of legal services. ${ }^{16}$ Consequently, denying indigent accused persons of this entitlement amounts to a denial of the right to legal representation and, thus, of the right to a fair trial. ${ }^{17}$ The right to legal aid today is recognised as one of the universally-guaranteed minimum protections for accused persons within the scope of fair trial rights in virtually all human rights instruments, both universal and regional. ${ }^{18}$

\section{Strategy of ratification of the right to legal aid in Ghana}

Due process rights of accused persons in Ghana are entrenched in the highest law of the land through the process of constitutionalisation,

11 See, eg, Amidu (n 7) 174.

12 Powell v Alabama 287 US 45 68-69 (1932), also affirmed in Gideon $v$ Wainwright 372 US 335 344-45 (1963).

13 See, eg, Didcott J in S v Khanyile \& Another 1988 (3) SA 795 (N) 800. See L Itoh 'Why South Africa should embrace Gideon: An analysis of the right to counsel and why it should be extended to all defendants' (2012) 44 International Law and Politics 951 at 963 . The author claims at 965 that '[s]ince standards for a fair trial include defendant's right to be represented by counsel, any violation of that right renders the trial unfair regardless of the cause including defendant's lack of resources'.

14 See Khanyile (n 13) 810.

15 A Sanders \& R Young Criminal justice (2000) 25.

16 As above.

17 PM Bekker 'The right to legal representation, including effective assistance, for an accused in the criminal justice system of South Africa' (2004) 37 Comparative and International Law Journal of Southern Africa 180.

18 See art 14(3)(d) United Nations General Assembly (UNGA) International Covenant on Civil and Political Rights (ICCPR) (1966); art 6(3)(c) European Convention on Human Rights; art 8(2)(e) American Convention on Human Rights; African Commission Principles and Guidelines on the Right to Fair Trial and Legal Assistance in Africa (2003) para H(a); UNGA Body of Principles for the Protection of all Persons under any Form of Detention or Imprisonment and Rule 93 of the UN Standard Minimum rules for the Treatment of Prisoners (1988) Principle 17(2); art 7(1)(c) African Charter on Human and Peoples' Rights. 
mainly for the purpose of reinforcing the call for their justiciability. ${ }^{19}$ However, among these procedural protections the nature and status of the right to legal aid as a module of the right to a fair trial remains somewhat unclear, particularly due to the unconventional procedure for its domestication adopted by the country.

Ghana's obligation to provide free state-funded counsel to indigent accused persons involved in criminal proceedings derives principally from its ratification, without any reservation, of articles 14(3) and 7(1) of the International Covenant on Civil and Political Rights (ICCPR) and the African Charter on Human and Peoples' Rights (African Charter) respectively. ${ }^{20}$ Generally, the Ghana's Bill of Rights, enacted under chapter 5 of its national Constitution, ${ }^{21}$ is a near total reproduction of the internationally-guaranteed norms in ICCPR. However, as far as the right to free legal aid is concerned, Ghana's approach to its domestication is largely influenced by the text of the African Charter and the jurisprudence of the African Court on Human and Peoples' Rights (African Court), the former being less elaborate than the provision on legal aid in ICCPR. ${ }^{22}$

In respect of the right to defence in criminal trials ICCPR guarantees, in a pertinent part, that the right of the accused is 23

to defend himself in person or through legal assistance of his own choosing $\ldots$ and to have legal assistance assigned to him, in any case where the interests of justice so require, and without payment by him in any such case, if he does not have sufficient means to pay for it.

The African Charter, however, marks an apparent departure from the content of this provision, which ostensibly and partly accounts for the stifled realisation of the right to legal aid and its dimmed effect in Ghana. Although guaranteeing 'the right to defence to include the right to be defended by counsel of choice', ${ }^{24}$ article 7(1) of the African Charter does not expressly prescribe a right to free legal aid. ${ }^{25}$ Likewise, article 19 of the Constitution of Ghana, which copiously enacts the fair trial rights of accused persons in criminal proceedings, does not guarantee a right to free legal assistance in cases where an

19 It is one the strategies of incorporation of international human rights norms into domestic legal systems. See GL Neuman 'Human rights and constitutional rights: Harmony and dissonance' (2002-2003) 55 Stanford Law Review 1881.

20 Ghana ratified ICCPR on 7 September 2000 and the African Charter on 24 January 1989.

21 In force since 3 January 1993.

22 Nganyi \& Others $v$ United Republic of Tanzania, Application 6/2013 (18 March 2016) para 166.

23 Art 14(3)(d) ICCPR.

24 Art 7(1)(c) African Charter.

25 Isiaga $v$ United Republic of Tanzania, Application 32/2015 (21 March 2018) para 77. 
accused person does not have the financial resources personally to secure legal representation. 26

This lacuna, however, does not relieve Ghana of its international obligation to provide free legal assistance to deserving indigent accused persons. The African Commission on Human and Peoples' Rights (African Commission), in discharging its duty to protect and promote human rights through the interpretation of the African Charter, gives due recognition to the right of indigent accused persons to free legal aid. Under its non-binding Principles and Guidelines on the Right to a Fair Trial and Legal Assistance in Africa, 27 each member state, including Ghana, is required to extend legal aid to accused persons who cannot afford to hire an attorney, where the interests of justice, assessed on the basis of the seriousness of the offence and the severity of the penalty, so require. ${ }^{28}$

The jurisprudence of the African Court also imposes a fundamental obligation on member states to provide free legal aid to indigent accused persons. The Court states that free legal aid is 'a right intrinsic to the right to fair trial, particularly, the right to defence guaranteed under article $7(1)(c)$ of the Charter'. ${ }^{29}$ Thus, to close the gap between the two standards under ICCPR and the African Charter, the African Court enjoins an interpretation of the obligations of member states that are also signatories to the ICCPR under article $7(1)(c)$ to be carried out in light of the provisions of article 14(3)(d) of ICCPR. ${ }^{30}$ Consequently, for indigent and lay accused persons charged with serious crimes carrying severe punishment and who do not have the means to recruit their own legal counsel, the interests of justice require member states to assign counsel free of charge. ${ }^{31}$ In the opinion of the African Court the essence of providing legal aid in appropriate cases is to ensure a fair judicial process, thereby avoiding

26 See clause 2(f) which guarantees only the right of accused persons to defend themselves in person or through legal assistance of their own choosing. This is contrasted with the position of the South African Constitution, eg, which guarantees a constitutional right of indigent arrested persons and accused persons to have legal practitioners assigned to them at the expense of the state, if injustice would otherwise result. See secs 35(2)(c) \& 35(3)(g) of the Constitution of the Republic of South Africa, 1996.

27 Principles and Guidelines (n 18).

28 Paras $\mathrm{H}(\mathrm{a})$ \& (b). See also Avocats sans Frontières (on behalf of Bwampamye) $v$ Burundi (2000) AHRLR 48 (ACHPR 2000) para 30.

29 Alex Thomas $v$ The United Republic of Tanzania Application 7/2013 (20 May 2016) para 123.

$30 \quad$ Nganyi case (n 22) para 165.

31 Mohammed Abubakari v United Republic of Tanzania Application 7-2013 (3 June 2016) para 138-139. The Court adopts the African Commission's standard for determining the interest of justice based on the seriousness of the offence and the severity of the punishment; Alex Thomas case (n 29) para 123; Nganyi case (n 22) para 168. Under the jurisprudence of the European Court, four factors are taken into account in determining whether the 'interest of justice' requires the provision of free legal aid: (a) the seriousness of the offence; (b) the severity of the potential sentence; (c) the complexity of the case; and (d) the social and personal situation of the defendant; Nganyi case (n 22) para 177. 
any possibility of a miscarriage of justice. ${ }^{32}$ More importantly, it remains the responsibility of the state to proprio motu offer free legal aid even in the absence of any express request by an accused. ${ }^{33}$ Herein lies Ghana's international obligation to provide legal aid to deserving indigent accused persons. ${ }^{34}$

Although lacking an express statement of the right to legal aid among the due process protections of accused persons under its Bill of Rights, the Constitution of Ghana also presents a rather strange and unconventional embodiment of a right to legal aid in article 294. The provision which figures in chapter 26, entitled 'Miscellaneous' and is outside of the scope of the Bill of Rights, provides as follows: ${ }^{35}$

(1) For purposes of enforcing any provisions of the Constitution, a person is entitled to legal aid in connection with any proceedings relating to this Constitution, if he has reasonable grounds for taking, defending, prosecuting or being a party to the proceedings.

(2) Subject to clause (1) of this article, Parliament shall by or under an Act of Parliament regulate the grant of legal aid.

(3) Without prejudice to clause (2) of this article, Parliament may under that clause provide for the granting of legal aid in such matters other than those referred to in clause (1) of this article as may be prescribed by or under that Act.

The legal basis and policy consideration undergirding this entitlement to legal aid and the seclusion of its implementation outside the scope of Bill of Rights are not readily known or ascertained in literature or the jurisprudence of the courts. Despite this observation, the right guaranteed in article 294 retains its status as a constitutionalised right, establishing parity of authority and prominence with other human rights protections in the Bill of Rights.

However, an intriguing question arises as to whether article 294 provides a due process or constitutional right to legal aid in criminal proceedings in Ghana. The position of the law in this respect also remains far from clear. ${ }^{36}$ In fact, some legal scholars have too hastily concluded that article 294 provides the constitutional source of a right

32 Nganyi case para 182.

33 Isiaga case (n 25) para 79; Nganyi case (n 22) para 182. Where an indigent accused person is not informed of this right or does not invoke this right, the onus is on the judicial authorities to activate the right. See Alex Thomas case (n 29).

34 Sight should not be lost of art 33(5) of the Constitution of Ghana which gives implicit recognition to the right to legal aid. It provides that '[t]he rights, duties and guarantees relating to the human rights and freedoms specifically mentioned in this chapter shall not be regarded as excluding others not specifically mentioned, which are considered to be inherent in a democracy and intended to secure the freedom and dignity of man'.

35 A similar provision was enacted under the earlier democratic Constitutions of Ghana, namely, arts 171 \& 212 of the 1969 and 1979 Republican Constitutions respectively.

36 See United Nations Office on Drugs and Crime (UNODC) Access to legal aid in criminal justice systems in Africa: Survey report (2011). 
to legal aid in criminal proceedings in Ghana. ${ }^{37}$ It is, however, undeniable that an unambiguous and plain reading of article 294(1) presents a limited scope for its enjoyment. The law clearly guarantees a right to legal aid to indigent persons involved in constitutional proceedings only. In practical terms it merely provides institutional support for the exercise of the civic right of every person in Ghana to institute an action in court for purposes of enforcing the Constitution itself. ${ }^{38}$ As a result, the right to legal aid in non-constitutional matters is not expressly guaranteed in article 294(1).

Notwithstanding this antithetical position, an argument may be made for the recognition of a constitutional right to legal aid in criminal proceedings from the provisions of article 294(1). ${ }^{39}$ Clearly, the language of the provision does not make any direct reference to a right to legal aid in criminal proceedings. However, proceedings relating to the enforcement of constitutional rights can be defined to include those instituted to enforce the due process rights of accused persons and criminal suspects guaranteed under the Constitution. ${ }^{40}$ When read along these conceptual lines, article 294(1) reasonably implies a constitutional right to legal aid of indigent suspects as far as proceedings instituted for the enforcement of their constitutional rights in criminal proceedings are concerned. ${ }^{41}$ Despite the logic of this deductive conclusion, one must be wary not to assume that a criminal proceeding seeking to establish the guilt or innocence of an accused person necessarily is a proceeding for the enforcement of a provision of the Constitution, nor is the provision in the nature of a due process right of accused persons as far as criminal proceedings are concerned.

In fact, clause (3) of article 294 reinforces the position that there is no express constitutional right to legal aid in Ghana except in constitutional proceedings. This provision empowers Parliament, while enacting laws to regulate the granting of legal aid in constitutional proceedings, also separately to enact laws regulating legal aid in nonconstitutional matters. ${ }^{42}$ It clearly underlines the distinction between the right to legal aid in constitutional proceedings and legal aid entitlements in non-constitutional matters, including criminal proceedings.

37 See, eg RAS Morhe 'An overview of legal aid for criminal cases in Ghana: The history and challenge of providing legal aid' (2012) 38 Commonwealth Law Bulletin 105.

38 See Ghana Constitution, art 2(1) which grants the right to any person in Ghana to institute legal actions for the enforcement of the provisions of the Constitution.

39 See Amidu (n 7) generally.

40 Amidu (n 7) 162.

41 Amidu 174.

42 Ghana Constitution, art 294(3): 'Without prejudice to clause (2) of this article, Parliament may, under that clause provide for the granting of legal aid in such matters other than those referred to in clause (1) of this article as may be prescribed by or under that Act.' 
The conundrum on the import of article 294 lies in the fact that this provision has not been judicially examined in terms of its guarantee or otherwise of a right to free legal assistance by indigent suspects and accused persons in criminal proceedings. Its effect as far as dealing with the stark reality of widespread cases of self-representation in criminal trials in Ghana also has yet to be considered. Again, a textual analysis of article 294 begs the question whether the provision intends an embodiment of the due process right to legal aid as recognised under international law. The main concern is that this provision does not appear to implement a right to 'free' legal assistance in cases of indigency. ${ }^{43}$ Although guaranteeing the provision of legal aid to indigent parties in legal proceedings, it stops short of endorsing a claim that such legal services are indeed to be 'free' or 'at no cost' to deserving accused persons and at the expense of the state. Where necessary, some level of financial commitment is required on the part of the beneficiaries of legal aid. ${ }^{44}$ This is despite the fact that the practical implementation of legal aid to a large extent envisages the provision of free legal services funded by the state. Thus, a finding to the effect that the ratification of the right to legal aid in Ghana falls below the standard envisaged under its obligation in international law indeed is conclusive.

\section{Legal aid schemes in criminal proceedings in Ghana}

As noted earlier, the Ghanaian Constitution entrusts the regulation of legal aid in all non-constitutional matters, including criminal proceedings, to Parliament. ${ }^{45}$ In the discharge of this obligation, the legislature has secured legal aid delivery under two public schemes in force in the country. These are the Court-Assigned Counsel Scheme established under the Courts Act ${ }^{46}$ and the Legal Aid Scheme created by the Legal Aid Commission Act (LACA). ${ }^{47}$ In practice these Acts constitute the two comprehensive forms of institutional assistance to indigent suspects and accused persons in criminal proceedings. ${ }^{48}$

By these schemes the courts in Ghana are tasked to assign statefunded counsel to deserving indigent and unrepresented persons

43 See UNODC (n 36) 6, which states that the reference in the Ghanaian Constitution to the right to legal aid is not clear.

44 See discussion in part 4 below.

45 Ghana Constitution, art 294(2): 'Parliament shall by or under an Act of Parliament regulate the grant of legal aid.'

46 Act 459 of 1993.

47 Act 977 of 2018. It repealed the then Legal Aid Scheme Act (Act 542 of 1997).

48 The two schemes also regulate the granting of legal aid in constitutional proceedings. The only requirement for the granting of legal aid in such cases is proof that the beneficiary of the right is a person who has reasonable grounds for taking, defending, prosecuting or being a party to the proceedings. Under the Court-Appointed Counsel Scheme, this determination is to be made by the judge or magistrate under sec 114(3) of the Courts Act, while the Legal Aid Commission assumes the same responsibility under sec 2(b) of LACA. 
facing criminal prosecution. In the alternative, such financiallydeprived suspects and accused persons may apply for free legal assistance under the LACA. Under both schemes, the provision of legal aid is more of a privilege than a right. Legal aid in the Ghanaian context is defined as

representation by a lawyer, including all such assistance as is given by a lawyer, in the steps preliminary or incidental to any proceedings or arriving at or giving effect to a compromise to avoid or to bring to an end any proceedings.

In practice, the two schemes apply diverse criteria for determining indigency and for granting legal aid, resulting in a lack of uniformity in the standards of legal aid administration in criminal matters generally. ${ }^{50}$

\subsection{Court-Assigned Counsel Scheme}

The Courts Act of Ghana sets up the hierarchy of courts and determines their respective jurisdictions. It also empowers the various courts under the legal system to assign lawyers by way of legal aid to unrepresented parties before them where the interests of justice so require. The Court-Assigned Counsel Scheme (CACS) applies generally to all private parties to litigation in both civil and criminal cases. Thus, in criminal proceedings the scheme applies to both suspects of crime and accused persons ushered before the court in criminal proceedings. Although this potentially is an effective regime to provide legal aid for the poor, the CACS has not been efficiently managed to deliver on its expectations, thus requiring a critical look at its operational framework.

\subsubsection{Operations of the Court-Assigned Counsel Scheme}

Section 114 of the Courts Act vests the superior courts of Ghana 51 with authority to assign a lawyer by way of legal aid to any suspect of crime or accused person who is too poor to hire counsel and who is

49 See Ghana Constitution, art 294(4), quoted above and as re-enacted by the Courts Act, sec 114(4). The Legal Aid Commission Act does not define legal aid.

50 This implementation strategy of the law on legal aid in Ghana is very different from the approaches adopted by countries such as the United States and South Africa which set very clear standards for qualification for free legal assistance. In the United States, eg, free legal representation is assigned to indigent accused persons in all cases, including misdemeanour cases where the accused person standing trial faces a penalty of a term of imprisonment however short. See Argersinger $v$ Hamlin 407 US 25 (1972). South Africa adopts the 'substantial injustice' test which applies a three-factor test in determining whether or not to assign counsel in trials of indigent accused persons. Basically, these have been listed to include the complexity of the case; the level of education and indigence of the accused; as well as the severity of the punishment or sentence. See PJ Schwikkard 'A constitutional revolution in South African criminal procedure?' in $P$ Roberts \& J Hunter (eds) Criminal evidence and human rights: Reimagining common law traditions (2012) 24.

51 In order of authority these are the Supreme Court, the Court of Appeal and the High Court/regional tribunals. 
facing criminal prosecution before the court or tribunal. ${ }^{52}$ The lower courts, consisting of the District and Circuit Courts, may also assign lawyers to the same categories of indigent suspects and accused persons appearing before them, but with the prior approval of the Chief Justice. ${ }^{53}$ This procedural requirement, in a judicial administrative system that is already engulfed in operational bureaucracies, presents another bottleneck in the swift implementation of the law. The majority of criminal cases in Ghana are brought before and handled by the District and Circuit Courts. A large number of accused persons on trial before these courts appear without legal representation. With the sheer volume of cases involving unrepresented accused persons appearing before them, the obligation imposed on Circuit Court judges and District Magistrates to refer every single decision to assign legal aid to an indigent accused person for the Chief Justice's approval is onerous and aberrant. It is also noted that the CACS is a contributory criminal legal aid and, by design, not an entirely free scheme of legal aid. Even though enacted to assist the indigent, it contemplates the exaction of a financial contribution from all persons who are assigned state-funded counsel. ${ }^{54}$

The assignment of legal representation by the various courts and tribunals under the CACS is subject to certain standards determined by a 'means' and a 'merit' tests. By the 'means' test, the CACS provides legal aid to accused persons who 'are financially unable to obtain the services of a lawyer'. ${ }^{55}$ Indigency in this context is widely defined. It is measured based on the economic status and financial inability of the accused to secure legal services at the market value. The financial implications for each offence for which an accused person stands trial is determined by the nature of the offence and the concomitant nature of the proceedings against him or her. The Ghana Bar Association (GBA) scale of fees, which details the certified legal fees according to the nature of the proceedings, provides a valuable guide in determining whether or not an accused person is in the position personally to afford counsel. ${ }^{56}$

The 'merit' test, for its part, is based on a judicial assessment of the need to assign counsel in any particular case. The purpose of the 'merit' test generally is to ensure 'a correct identification of such cases where injustice would arise if legal aid was refused'. ${ }^{57}$ The law grants

\footnotetext{
52 Sec 114(1) Courts Act.

53 Sec 114(2) Courts Act.

54 Secs 114(6) (b) \& (c) of the Courts Act, which contemplate legal aid beneficiaries to contribute towards the cost of legal aid. See also $n 82$ below.

55 Sec 114 (1) Courts Act.

56 Ghana Bar Association (n 3).

57 Sanders \& Young (n 15) 494. Also at 496 the authors note, on the contrary, that '[i]t cannot be safely predicted in advance which cases might lead to injustice, if representation was not provided. Good legal representation can lead to the emergence of previously hidden aspects of the case, render problematic the prosecution's version of events, and raise questions about the integrity of the procedures followed.'
} 
a discretion to the judge or magistrate to assign counsel only where in his or her opinion it is in the interests of justice that the indigent party should have legal aid. ${ }^{58}$ The factors to be taken into account in determining the 'interests of justice' have not been determined by law or by the courts. This void notwithstanding, Ghana remains obligated under the jurisprudence of the African Court to adopt a standard for determining the interests of justice based on the seriousness of the offence and the severity of the punishment. ${ }^{59}$ The law, however, vests the courts with a wide discretion in applying the 'interests of justice' test. It imposes a permissive duty on the judge, who 'may' assign counsel within the wide parameters only of his or her sole discretion. ${ }^{60} \mathrm{It}$ is therefore expected that in certain instances legal aid may be refused even in cases involving difficult points of law and/or facts. 61

The principal reason for subjecting the substantive right to statefunded counsel to this exercise of discretion by the judge in cases of indigency is mainly financial. There is an almost indefeasible truth expressed in the country's inability to provide counsel for each and every deserving indigent suspect or accused person. Therefore, guaranteeing an unqualified right to legal representation for all indigent accused persons who are unable personally to afford counsel would certainly paralyse an already overburdened criminal justice system. The situation in Ghana, therefore, rejects the view that the state inherently is saddled with the responsibility to afford counsel to every accused person who cannot provide one for him or herself. The underlying justification for this strategic assumption of legal aid is mainly two-fold. The first alludes to the fact that legal representation cannot be said to be a necessary condition for the effective defence of every criminal charge. The second relates to the impracticability of obtaining state-funded counsel for every accused under any legal aid scheme.

Again, lawyers assigned under the CACS do not render legal services pro bono. They are entitled to be paid legal fees from the Consolidated Fund, ${ }^{62}$ as determined by the Minister of Justice, acting in consultation with the Chief Justice. ${ }^{63}$ Thus, it is a state-funded scheme. Realistically, there is a limit both to the number of lawyers who can provide legal assistance and to the funds that the state can

\footnotetext{
58 Secs 114(1) \& (2) Courts Act.

59 See $\mathrm{n} 31$.

60 Sec 114(1) of the Courts Act, which states in part that the superior courts 'may assign a lawyer by way of legal aid to a party to proceeding before the court or tribunal' (my emphasis).

61 Saunders \& Young (n 15) 494, stating a similar observation in respect of the legal aid scheme in England.

62 Defined by the Ghana Constitution, art 176(1). It refers to a fund containing 'all revenues or moneys raised or received for the purposes of, and on behalf of the government and other revenues raised on received in trust, for or on behalf of the government'.

63 Sec 114(5) Courts Act.
} 
reasonably be expected to make available to sustain this scheme of legal aid. In the end, the leading objective of the CACS must be to ensure that injustice does not arise through an accused being prevented by a lack of means from effectively defending him or herself before the court. The overriding standard must be that in all cases the accused must be given a reasonable opportunity to bring forward and argue all the matters that may constitute a defence to a charge or which can mitigate the gravity of the offence. ${ }^{64}$

\subsubsection{Practical problems associated with the operations of the Court- Assigned Counsel Scheme}

Generally, the CACS has not been effectively implemented. Despite its institution more than 25 years ago the scheme has not been efficiently used to assist the increasing number of indigent suspects and accused persons who have no financial means of accessing legal services. ${ }^{65}$ However, the real problem is an administrative lapse in the process of implementation of the scheme. Section 114(6) of the Courts Act mandates the Minister of Justice in consultation with the Chief Justice to make regulations for the full operation of the CACS. The anticipated legislative instrument is intended to postulate such modalities, including (a) the conditions for the grant of legal aid; (b) the assessment of disposable capital, income or property for the purposes of contribution towards legal aid; (c) the extent of contribution to be made by the beneficiary of legal aid; as well as (d) the right to and nature of legal advice. ${ }^{66}$ This statutory directive to date has not been carried through. Courts presently assign counsel to deserving indigent and unrepresented accused persons, but on a very small scale. This limited practice, however, essentially is more a call to offer pro bono services than it is about implementing the CACS.

In addition to this administrative lapse, other general reasons account for the non-performing status of the CACS. A serious concern involves a general sense of dissatisfaction with the quality of legal services rendered by some lawyers assigned to provide legal aid in Ghana. ${ }^{67}$ Not much attention is paid to the nature and quality of legal services rendered by court-appointed counsel to indigent accused persons. There are no institutional mechanisms to evaluate and assess the discharge of their services as far as providing effective assistance to the beneficiary suspect or accused person is concerned. According to a survey report compiled in 2011 on Access to Legal Aid in Criminal

64 See, eg, Saunders \& Young (n 15) 494-495.

65 Amidu (n 7) 176.

66 Secs 114(6) \& (7) Courts Act.

67 See observations by Dotse JSC in Zainabu Naske Bako-Alhassan v Attorney-General [24/04/2012] Suit j1/22/2012 (unreported). 
Justice Systems in Africa, ${ }^{68}$ '[le]ss than $20 \%$ of cases assigned to lawyers are successfully completed every year' in Ghana. The study also found that cases assigned to lawyers for legal assistance under the CACS generally are not given the necessary attention. Equally, there is no proper supervision to ensure effective delivery. ${ }^{69}$ As a result, indigent accused persons confronted with choosing between an unavailable and uncaring counsel and self-representation would opt for the latter as the only real alternative to legal representation. The Ghanaian bench also appears generally to have dampened the rigours of its statutory power to assign counsel to deserving indigent accused persons. The courts rarely exercise their power to appoint counsel for indigent accused in the interests of a fair trial and justice as the law requires. $^{70}$ This judicial attitude, however, may be logically defended by the lack of the long-awaited regulations needed to fully implement the CACS.

Consequently, there are many poor persons who are arrested, restricted and detained or charged with a crime and who continue personally to defend their cause in criminal proceedings before the courts. The sole exception concerns cases where accused persons are charged with the capital offence of murder who, according to the practice of the courts, are automatically assigned counsel for their defence at the trial. ${ }^{71}$

A clarion call made by Taylor J more than three decades ago to stimulate the courts' exercise of their power to assign counsel to indigent accused persons in deserving cases remains relevant today. As the judge stated, it is about time Circuit Court judges and District Court magistrates that adjudicate the majority of criminal cases turn their attention to the provisions of section 114 of the Courts Act in order to avoid unnecessary injustices that have become all too frequent in the operations of the criminal law. ${ }^{72}$ As he held in his judgment,

[i]n order to safeguard the liberty of citizens, it was essential that indigent and illiterate persons, ignorant of the legal process and accused of serious crimes carrying harsh penalties, were not left to their own devices but assigned counsel by way of legal aid. ${ }^{73}$

Finally, the statutory directive to exact financial contributions on the already indigent accused persons who have been assigned legal

68 See UNODC (n 36) 13, referring to the National Development Planning Commission, Government of Ghana, Poverty Reduction Strategy Paper - 2006, Annual Progress Report, IMF Country Report 09/237 Washington DC, International Monetary Fund, 2009, www.imf.org/external/pubs/tf/scr/2009/ cr09237.pdf (accessed 26 August 2016). This is compared to the estimated percentage of legal aid cases completed in 2006 which is approximately $18 \%$.

69 As above.

70 Amidu (n 7) 173.

71 Amidu 159167.

72 Taylor J in Kpekero $v$ The Republic [1980] GLR 580 588, obiter.

73 As above. 
representation may rather stifle the achievement of the noble cause of the CACS. In addition to their financial contributions, suspects or accused persons who are assigned counsel are not exempted from paying the prescribed fees in respect of court documents, processes or costs of preparing appeal records. The CACS in essence remains a scheme of legal aid that is not free. If meaning is to be given to the provision of legal aid by way of assignment of free legal representation within the intendment of the universal policy under articles 14 and 7(1) of ICCPR and the African Charter respectively, then legal steps must be taken to ensure that legal assistance offered under the CACS is provided at no cost to a beneficiary who is unable to pay. It is very important at this stage of the development of the country to align the Ghanaian position on the law with its obligations to provide truly free legal aid under international law.

\subsection{Ghana Legal Aid Scheme}

The Ghana Legal Aid Scheme (GLAS) is a public service body within the Ghanaian justice delivery system. ${ }^{74}$ It is established under the Legal Aid Commission Act (LACA) alongside the CACS, to ensure the effective delivery of legal aid to indigent persons in both civil and criminal proceedings in Ghana. More specifically, the GLAS is tasked under its enabling statute to provide legal assistance to indigent litigants and all such persons who institute proceedings for the prosecution or defence of their rights under the Constitution. ${ }^{75}$ It seeks to ensure that this category of persons are not denied justice simply because they are unable personally to afford counsel of their choice. $^{76}$

In criminal proceedings, more particularly, the GLAS aims to protect indigent suspects of crime and accused persons against the powerful and resourced office of the prosecution represented by the Attorney-General. ${ }^{77}$ The GLAS establishes a Public Defenders' Division to assist indigent accused persons and suspects of crimes, whether on bail or on remand, in order to guarantee their human and fair trial rights. ${ }^{78}$ One may theorise that the GLAS provides a platform where indigent suspects and accused persons effectively can assert their right to legal aid in the criminal justice system. These laudable policies undergirding the establishment of this scheme, however, remain goals yet to be achieved by the criminal justice administration.

74 Welcome to Legal Aid Scheme, Ghana, http://www.legalaidghana.org/web/ (accessed 1 March 2019).

75 Sec 2 LACA.

76 Republic v Lukman [2003-2005] 1 GLR 125130.

77 Amidu (n 7) 127.

78 Sec 22 LACA. 


\subsubsection{Operations of the Ghana Legal Aid Scheme}

The implementation of the GLAS is entrusted entirely to the authority and direction of the Board of Legal Aid Commission which is tasked to assign legal aid to deserving indigent persons facing criminal proceedings. Lamentably, legal aid in criminal trials under the GLAS also is a privilege and not a right. Indigent accused persons are bound to make an extra-judicial application for legal aid to the Commission, which is vested with the discretion either to grant or refuse the application. ${ }^{79}$ A refusal decision may be appealed to a Review Committee. ${ }^{80}$ The application process is not entirely free. The Commission may request an applicant to pay a fee to cover expenses incidental to the determination of his or her application. ${ }^{81}$

As in the case of the CACS the GLAS essentially is a contributory legal aid scheme. The Commission may require an applicant to pay an amount by way of contribution or towards the payment of costs awarded against him or her in the proceedings. ${ }^{82}$ In addition to receiving the free assistance of a lawyer an accused person who qualifies for legal aid under the GLAS also is exempted from paying the prescribed fees in respect of the filing of court processes, the cost of judicial forms, the cost of service of filed processes and the cost of preparing records of proceedings and records of appeal. ${ }^{83}$

The GLAS identifies two categories of accused persons who may be entitled to legal aid, and applies two main criteria in setting up the qualification thresholds for legal aid. First, the LACA provides a 'merit' test by guaranteeing an automatic grant of legal aid to all unrepresented accused person charged with offences punishable by life imprisonment. ${ }^{84} \mathrm{~A}$ patent shortfall in the law is its omission of accused persons charged with capital offences from the scope of persons who automatically qualify for free legal assistance. In this context, the predecessor law to the LACA, the Legal Aid Scheme Act $(\text { LASA })^{85}$ provided broader coverage as it guaranteed full and unqualified statutory rights to free state-funded counsel to all accused persons charged with offences punishable by death or life imprisonment. ${ }^{86}$ This lapse must be addressed.

The second category of accused persons entitled to legal aid under the GLAS is defined by a 'means' test. This class refers to indigent

79 Secs $38 \& 39$ LACA.

80 Secs $46-48$ LACA.

81 Sec 39 LACA.

82 Sec 40(1) LACA. See also sec 3(2)(h) enjoining the Commission to 'specify the circumstances in which contributions shall be made by legally-assisted persons and the means of calculation of the contribution'.

83 Sec 45 LACA.

$84 \mathrm{Sec} 22(\mathrm{~g})(\mathrm{i})$ LACA.

85 Act 542 of 1997, immediately in force before the entry into force of the LACA.

$86 \mathrm{Sec}$ 24(2) LACA. These offences include treasonable offences and murder punishable by death, as well as manslaughter which is punishable by life imprisonment. 
accused persons charged with offences other than crimes punishable by a term of imprisonment for life. It refers to accused persons who, objectively assessed, cannot afford the services of a lawyer and desire to be represented by counsel. ${ }^{87}$ Strikingly, the scheme does not set the threshold of indigency. The LACA, however, vests the Commission with wide discretionary powers to determine those persons who in its opinion may be granted legal aid. ${ }^{88}$ The Commission equally is vested with the power to set the threshold of indigency. ${ }^{89}$ For such indigent accused persons the Commission may in each case determine conditions for granting legal aid, including the Commission's entitlement to costs recoverable in any proceedings and the payment by the applicant of contributions to the Commission. 90 The Commission equally determines priorities in the provision of legal aid between different applicants. ${ }^{91}$ The law guarantees the right of an indigent applicant only to appeal a refusal decision of the Commission before a Legal Aid Review Committee. ${ }^{92}$ Sadly, the Committee meets once every three months, a period long enough to jeopardise the rights of an accused in a matter pending before the court.

In any case, applying the 'means' test requires an objective assessment of the prevailing socio-economic circumstances of the times as well as the overall financial set-up of legal service delivery in the country. The net is wide enough to accommodate a good number of accused persons indigent enough as to be unable to afford legal services. In determining the 'means' test the Commission should, however, guard against adopting the minimum wage as a threshold for indigency, as was the case under the repealed LASA. This standard of determining indigency under the old regime indubitably was one of the main causes of the high incidence of self-representation in criminal trials in Ghana. The vulnerability of such a standard lies in the fact that using the minimum wage as the threshold for indigency leaves a sizeable number of the population outside the scope of protection. There are individuals who earn the minimum wage but yet are unable to afford the high cost of legal services. ${ }^{93}$

The present daily minimum wage in Ghana is $\mathrm{GH} \not 10,65$, the approximate equivalent of less than $\$ 2,00$, making an approximate monthly minimum wage of $\mathrm{GH} ₫ 320$, being the approximate equivalent of less than $\$ 60$. Disturbingly, even the monthly minimum wage in Ghana falls far below the GBA-approved fees for only initial consultations with lawyers in criminal matters. ${ }^{94}$ Consequently, a number of accused persons who may not be standardly indigent may

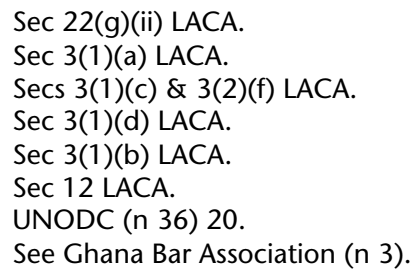


still be unable to afford the high cost of legal services, and thus are compelled to appear unrepresented in criminal proceedings. ${ }^{95}$ The Commission must take a cue from the UN Principles and Guidelines on Access to Legal Aid in Criminal Justice Systems of 2012 in establishing the parameters of the 'means' test under the LACA. To that effect Guideline 1 provides that

[w] henever states apply a means test to determine eligibility for legal aid, they should ensure that persons whose means exceed the limits of the means test who cannot afford, or do not have access to, a lawyer in situations where legal aid would otherwise been granted and where it is in the interests of justice to provide such aid, are not excluded from receiving assistance. ${ }^{96}$

It is also noted that the process of vetting legal aid applications by the Commission is insufficiently regulated. Guidelines for the approval or rejection of applications are unknown and rest purely within the discretion of the Commission. ${ }^{97}$ There are no legal instruments or regulations guiding the exercise of this discretion. The entire process of considering legal aid applications, therefore, lacks the necessary transparency. It is crucial that such a power in the hands of the Commission should be exercised with the utmost judicious consideration. In exercising its authority to grant or refuse legal aid, the Commission must be guided by the administrative threshold of fairness and candidness, and eschew tendencies of arbitrariness, capriciousness or bias either by resentment, prejudice or personal dislike. ${ }^{98}$

\subsubsection{Problems associated with operations of the Ghana Legal Aid Scheme}

Generally, and in more practical terms, the GLAS has been largely ineffective and is saddled with practical and operational difficulties. It generally takes little commendation beyond the letters of its mission statement and enacting provisions. The GLAS is funded by money provided by Parliament as well as by donations and gifts. ${ }^{99}$ Notably, the problem of chronic underfunding basically has paralysed the operations of the scheme. ${ }^{100}$ The GLAS is poorly funded and its budget is woefully inadequate to sustain its operations. The GLAS

95 See also WB Harvey Law and social change in Ghana (2015) 192-193, also indicating that many indigent accused persons have no assistance, except sometimes benefiting from the charitable work of individual lawyers.

96 UN (n 4) Guideline 1, para 41(a).

97 Sec 3(d) LACA. The Commission is solely responsible for considering and approving applications for legal aid. See also Amidu (n 7) 180, who states that '[t]he cumbersome process and requirements involved do not make it useful to many indigent arrested, restricted, detained or accused persons as it is dependent on an extra-judicial application to a Board [now a Commission] by the affected person. His case may have been disposed of before it is granted.'

98 See Ghana Constitution, art 296.

99 Sec 27 LACA.

100 See Latham \& Watkins (n 6) 230 fn 14. 
works with legal personnel consisting of legal practitioners. ${ }^{101}$ Every lawyer assigned to provide legal aid under the scheme is entitled to be paid such remuneration out of the Legal Aid Fund as the Commission may determine. ${ }^{102}$ Unfortunately, the GLAS has been unable to fully settle its financial obligations to legal practitioners selected to work for it. ${ }^{103}$ The magnitude of cases involving selfrepresented illiterate and indigent accused persons in the various courts across the length and breadth of the country attests to the financial struggle and failings of the scheme.

The GLAS also is understaffed and ill-equipped. There is a shortage of experienced lawyers working for the scheme generally due to low remuneration and poor access to legal aid offices. ${ }^{104}$ The sheer number of suspects and accused persons who require legal aid has overwhelmed the scheme which already lacks the systems and resources to ensure adequate legal representation for the indigent. As of the year 2018 the GLAS could boast only of a paltry number of 23 lawyers serving a whole country of over 28 million people, both in civil and criminal cases. ${ }^{105} \mathrm{~A}$ relatively small number of lawyers in the country are available to attend to the needs of the growing population. 106 The GLAS intends to consolidate a pool of lawyers from across the country to work as its legal personnel to provide legal aid to the poor. The National Service Board ${ }^{107}$ is mandated to assign to the GLAS a number of lawyers to their national service with the scheme. ${ }^{108}$ In addition, a call is made to lawyers voluntarily to offer legal aid. ${ }^{109}$ It is obvious that this plan to boost the human capacity under the GLAS has not yet attained the necessary result. Consequently, many suspects and accused persons who would otherwise benefit from legal aid today appear unrepresented in criminal proceedings.

Therefore, it is not surprising that in the year 2012 a Ghanaian citizen issued a writ of summons in the Supreme Court of Ghana

101 Sec 18 LACA.

$102 \mathrm{Sec} 35(\mathrm{c})$ LACA.

103 See also http://www.legalaidghana.org/web/index.php/news/latest-news (accessed 13 February 2016).

104 Generally, see Morhe (n 37).

105 In 2013 there were 14 lawyers. See 'Access to justice in Africa: The experience of the legal aid scheme in Ghana' 21 February 2013, http://www.leitnercenter.org/ news/94 (accessed 25 August 2016). There are only 23 lawyers under the Ghana Legal Aid Scheme for a population of 28 million people, https://www.amnesty. org/en/countries/africa/ghana/report-ghana/ (accessed 24 February 2018).

106 UNODC (n 36) 11. There are currently fewer than 4000 lawyers serving the entire country.

107 Established under the Ghana National Service Act 426 of 1980. It is in charge of the control and management of the national service scheme.

108 Sec 18(c) LACA. The service requires newly qualified graduates to undertake a period of compulsory service to the state as part of their civic responsibility.

109 As of the year 2017, there were approximately 200 private lawyers offering legal aid. See http://www.legalaidghana.org/web/index.php/news/66-las-policy-dialo gue-on-the-use-of-paralegals-in-ghana (accessed 1 March 2019). 
requesting for a formal recognition of the legal status of lay persons in representing themselves in court. ${ }^{110}$ She requested the Court to give due recognition to the right of private individuals that are nonprofessional lawyers to access the law courts in all manners of cases and to have equal treatment with lawyers when conducting their own cases. She again sought a formalisation of the rights of unrepresented litigants in the law courts, such that the rules of procedure applicable in the courts of law will not effect any hardship and/or prejudice against them. Her reliefs also included the simplification and streamlining of the rules of procedure to help such self-represented persons to prosecute their cases effectively, even if not professionally efficiently. ${ }^{111}$ Much to the chagrin of the plaintiff and all persons unable to afford counsel and desirous to represent themselves in legal proceedings before the courts, the Supreme Court dismissed her claims. The Court held that the legal system in Ghana cannot have a pluralistic or dualist system of procedure for self-represented and represented litigants. In brief, there can be no special concessions for self-represented non-professional litigants within the general framework of the rules of procedure.

The Supreme Court in the judgment delivered by Dotse JSC also minced no words when in his introductory remarks he held that the suit in a way was a condemnation of the legal aid system in Ghana. As he rightly observed, the GLAS appears not to have any regulatory framework to ensure that persons who benefit from legal aid are given competent legal advice and service. The Supreme Court recommended a review of the then Legal Aid Scheme Act to ensure that the conduct of legal aid cases assigned to lawyers is monitored by authorities in the scheme. This is to prevent situations where accused persons would desire personally to handle their briefs in court rather than through counsel assigned under legal aid. With the coming into force of the LACA and its lack of provisions on this matter of concern to the judiciary, not much change is expected in this regard.

Again, the Supreme Court re-reinforced the call for the Ghana Bar Association to consider institutionalising a mandatory pro bono legal scheme for indigent litigants. There is no formalised pro bono system in Ghana and few lawyers actually provide pro bono services in Ghana. ${ }^{112}$ A few civil society organisations also volunteer free legal assistance to indigent accused persons. Although their contributions are highly lauded, these private organisations generally face financial and logistical challenges in meeting the growing demand for free legal services in criminal matters in the country. ${ }^{13}$ The way of out

110 Zainabu Naske Bako-Alhassan (n 67).

111 As above.

112 See Latham \& Watkins (n 6) 231. See also n 109.

113 Some organisations include Help Law Ghana; Legal Resource Centre; Women's Initiative for Self-Empowerment; International Federation of Women Lawyers; Ark Foundation; Access to Justice run by the African Centre for Development and Policy; and Pro Bono Lawyers Network. 
this impasse is government's re-dedication to the values of fair trial and criminal justice for all accused persons who are too poor to secure the services of counsel. The state must strengthen the workings of the GLAS through a radical enhancement of its financial resources and seek an effective implementation of the provisions the LACA to increase the capacity of its working force.

\section{Way forward}

Put together, the operations of the legal aid schemes attempt to fill the gap in the law created by the explicit absence of a constitutional due process right to free legal aid in criminal proceedings in Ghana. However, all the legal provisions and institutional efforts towards providing free legal assistance in cases of indigency woefully have failed to cater for the large number of deserving suspects and accused persons. Access to legal aid generally is unavailable at all stages of the criminal proceedings and its coverage is most inadequate to deal with the large number of individuals who are unable to procure the everincreasing expensive services of counsel. With these facts, the only practical implication will be the continuing rise in the number of selfrepresented accused persons in criminal trials.

If the problem of self-representation in criminal proceedings is to be addressed effectively, due consideration must be given to the need to address the various legislative, administrative and financial problems that have engulfed the smooth operation of legal aid in the country. Most importantly, the proper domestication of the text of article 14(3) of ICCPR on the right to assignment of free state-funded counsel in cases of indigency must be done. This process must translate into a clear enactment of a right to legal aid which must be elevated to the level of a constitutional right. ${ }^{114}$

Again, the Ghanaian criminal justice system must take a cue from the useful strategies advocated under the Lilongwe Declaration on Accessing Legal Aid in the Criminal Justice System in Africa ${ }^{115}$ to advance the cause of legal aid in Ghana. A first engagement will require expanding the scope of legal service providers. Beyond the government's efforts legal aid service providers should include a wide range of stakeholders, including non-governmental organisations (NGOs); community-based organisations (CBOs); non-religious organisations; faith-based organisations; professional bodies and associations; as well as academic institutions. ${ }^{116}$ In that case, judi-care programmes, justice centres and law clinics can be developed and added to present schemes of legal aid. ${ }^{117}$ The efforts of those NGOs

114 See, eg, UN (n 4) Principle 1(14).

115 Lilongwe Declaration (n 9).

116 UN (n 4) Principle 1.

117 UN (n 4) Principles $6 \& 7$ and Guideline 16(70). 
that already are in the business of providing legal aid must be commended and also coordinated. In addition, the criminal justice system must aim at diversifying legal aid service providers in the country. At present, only lawyers qualify to provide legal aid services in pre-trial and trial proceedings in criminal matters. The number of practising lawyers in criminal matters, however, is inadequate to meet the legal aid needs of the rising number of suspects and accused persons in the country. ${ }^{118}$

To that effect Ghana must follow through its agenda to recognise the status of non-lawyers in criminal proceedings, including law students in legal clinics, legal assistants and paralegals. ${ }^{119}$ Working towards attaining 'Goal $16^{\prime}$ of the Sustainable Development Goals on legal empowerment and access to justice for all, the LACA seeks to address the challenges of access to justice and envisages the development of a system of paralegals and paralegal assistants in legal aid delivery. ${ }^{120}$ Steps must be accelerated to establish structured accredited courses to train such paralegals.

It is also important for the government to exhibit a political will to address the financial challenges of the public legal aid schemes. The government must allocate sufficient funds to legal aid schemes to meet the costs of their administrative and operational needs. ${ }^{121}$ The Ghanaian government already has adopted the Constitutional Review Commission's proposal to establish the GLAS as an independent constitutional body which is to be funded by other independent constitutional bodies. ${ }^{122}$

It is necessary for the government and the private sector to collaborate to raise the necessary funding. ${ }^{123}$ The Bar Association, the General Legal Council and the judiciary must define standards for the provision of pro bono services by lawyers. Pro bono legal services must be recognised as an important duty in the legal profession. Lawyers should be provided and assisted with the necessary logistical and professional support systems to ensure an effective system of pro bono legal services. For now, in the absence of a legislation mandating the provision of pro bono legal services in Ghana, there is the need to encourage such free services as part of lawyers' ethical duties. However, steps must be taken to crystallise this ethical duty into a legislative requirement for the annual renewal of practising licences for lawyers and law chambers. Finally, legal education in Ghana must be made more accessible to persons intending to profess as lawyers,

118 http://www.legalaidghana.org/web/index.php/news/66-las-policy-dialogue-onthe-use-of-paralegals-in-ghana (accessed 1 March 2019).

119 Lilongwe Declaration (n 9) Principle 7); UN (n 4) Guidelines 14(67) \& 16(71)(e).

$120 \operatorname{Sec} 3(2)(\mathrm{g})$ LACA.

121 UN (n 4) Guideline 12(16)(a); Lilongwe Declaration (n 9) Principles 1 \& 9.

122 http://constitutionnet.org/sites/default/files/crc_research_report.pdf 667 para 176 (accessed 1 March 2019). See also http://ghana.gov.gh/images/documents/crc report_white_paper.pdf 43 (accessed 1 March 2019).

123 Principle 9 Lilongwe Declaration (n 9). 
as it remains the surest route towards ensuring wider access to justice for all.

\section{Conclusion}

Several legal and regulatory barriers contrive to whittle down the value and benefits of the right to legal aid to needy accused persons in criminal proceedings in Ghana. The domestication procedure of the right to legal aid and the legal strategies for its implementation have been the bane of legal aid delivery in the country, which is obviously in dire straits. For now, the laudable parliamentary intentions in enacting these laws for the benefit of indigent accused persons and suspects of crime who are unable personally to hire the services of counsel remain generally illusory. The rhetoric of a fair trial and the quality of justice delivery in criminal proceedings continue to be eroded by the stark imposition of self-representation in cases where accused persons cannot afford legal representation. Eventually, as legal aid remains out of the reach of indigent accused persons in violation of their right to a fair trial, it is only a matter of time before the courts lose judicial legitimacy. Having ratified the Protocol to the African Charter on the Establishment of the African Court which allows individuals and NGOs to bring cases on human rights violations to the African Court, Ghana stands to face a myriad of suits on account of its failure to provide legal aid.

Great opportunities exist to reinforce the general scheme of legal aid in Ghana in order to redress the degenerating trends of involuntary self-representation arising from the sole factor of the poverty of accused persons or criminal suspects. The first decisive initiative falls on the country to take a bold step for the full implementation of the text of article 14(3)(d), as implied by article 7 of the African Charter, regarding the provision of free legal assistance to all accused persons who do not have the financial means to secure legal representation. The remaining remedial measures must take the form of policy changes and financial commitments towards revamping the operations of legal aid under the current schemes of legal aid. 